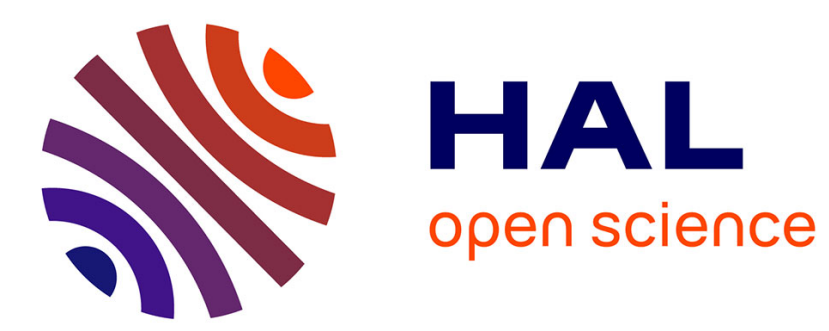

\title{
Tooth dimensions and body size in a Pygmy population
} Fernando Ramirez Rozzi, Alejandro Romero

\section{To cite this version:}

Fernando Ramirez Rozzi, Alejandro Romero. Tooth dimensions and body size in a Pygmy population. Annals of Human Biology, In press, pp.1-8. 10.1080/03014460.2019.1673482 . hal-02359639

\section{HAL Id: hal-02359639 \\ https://hal.science/hal-02359639}

Submitted on 19 Nov 2019

HAL is a multi-disciplinary open access archive for the deposit and dissemination of scientific research documents, whether they are published or not. The documents may come from teaching and research institutions in France or abroad, or from public or private research centers.
L'archive ouverte pluridisciplinaire HAL, est destinée au dépôt et à la diffusion de documents scientifiques de niveau recherche, publiés ou non, émanant des établissements d'enseignement et de recherche français ou étrangers, des laboratoires publics ou privés. 


\section{Tooth dimensions and body size in a pygmy population}

Running title: Tooth dimension and body size in Pygmies

$$
\text { Fernando V. Ramirez-Rozzi }{ }^{1,2, *} \text {, Alejandro Romero }{ }^{3}
$$

${ }^{1}$ UMR 7206 Eco-anthropologie CNRS, Musée de l'Homme, 17 place du Trocadéro, 75116 Paris.

${ }^{2}$ EA 2496, Faculté de Chirurgie Dentaire, Université Paris, Montrouge, France 92120

${ }^{3}$ Departamento de Biotecnología, Facultad de Ciencias, Universidad de Alicante, Alicante, Spain 03080

*Corresponding author: Dr. Fernando V. Ramirez-Rozzi

UMR 7206 CNRS

EA 2496

Faculté de Chirurgie Dentaire

1 rue Maurice Arnoux, 92120 Montrouge, France

fernando.ramirez-rozzi@cnrs.fr

Total words: 6720

Tables: 9

Figures: 1 


\title{
Tooth dimensions and body size in a pygmy population.
}

\author{
Abstract \\ Background: The relationship between tooth size and stature has been analyzed extensively at \\ the interspecies level but has received less attention at the intraspecies level. The relationship \\ between these two parameters does not seem to be the same among modern human \\ populations.
}

Aim: The aim of this study is to analyze the relationship between tooth dimensions and body measurements in the Baka pygmies.

Subjects and methods: Height, weight and tooth dimensions were obtained for 45 adult Baka females and 17 males from Le Bosquet (Cameroon). Correlations were obtained between the variables and compared to results for other human populations.

Results: The Baka population is distinctive in the small number of significant correlations. Only two bucco-lingual diameters among Baka females show any significant correlation with height. The lack of significant correlations between tooth dimensions and body dimensions among the Baka means that changes in body size are accompanied by random variations in tooth dimensions.

Conclusion: These lack of correlations may be accounted for by the impact of environmental effects on the somatic growth of the Baka producing a pygmy phenotype adapted to live in the forest. It is worth noting that many correlations become significant when sexes are pooled.

Keywords: tooth diameters, tooth area, stature, correlation, Baka pygmies 


\section{Introduction}

The relationship between tooth size and body size has been analyzed extensively at the interspecies level (e.g. Wood 1979; Steudel 1982; Vinyard and Hanna 2005; Ungar 2014). Less attention has been given to analyzing this relationship within species, probably because of the difficulties that arise in dealing with a sample made up of living individuals. Most intraspecies studies have been carried out using museum collections, with the disadvantage that tooth dimensions are compared with cranial or post-cranial measurements that are assumed to be a good proxy for individual body size (limb bone dimensions [e.g. Anderson and Thompson 1973; Anderson et al. 1977; Lavelle 1977]; skull dimensions [Lavelle 1974; Steudel 1982] and body weight [Wolpoff 1973; Anderson et al. 1977].

However, some pioneering work on the relationship between tooth size and body size has been carried out at the intraspecies level by Garn and colleagues who analyzed Ohio individuals participating in the Fels study, and although they did not find any correlation in

the first study (Garn and Lewis 1958), they later observed (Garn et al. 1968) that 12/28 tooth diameters (MD and BL) in males and 5/28 tooth diameters in females correlated significantly with stature. Correlations have also been assessed among African Americans (Henderson and Corruccini 1976) and significant correlations were again found to be more numerous among males (21/32 tooth diameters) than females (1/32 tooth diameters). Wolpoff (1985) reported 9/32 correlations in females and 5/32 in males for a Yuendumu sample of Australian aborigines. In contrast, no relationship was reported by Filipson and Godson (1963) for Swedes and by Anderson et al (1977) for Canadians, but these two studies only analyzed some dimensions of the anterior teeth and the Anderson et al sample was made up of individuals of 16 years of age, so individuals had most probably not yet reached their adult stature. Recently, with attention focused on identifying individual victims of natural disasters, 
terrorism attacks and transportation crashes, an increase in studies at the population (i.e. intraspecies) level has been noted (Yadav et al. 2016).

Homo sapiens is a polymorphic species with wide variations in body size between populations, which are certainly due to particular changes in a common overall pattern of growth (e.g. Johnson et al. 2011; Ramirez Rozzi et al. 2015; Cole and Mori 2017). Pygmy groups living in Equatorial Africa are characterized by a small adult stature and it was recently shown that tooth eruption in Baka pygmies occurs at an early age (Ramirez Rozzi 2016). Shea and Gomez (1988) analyzed the relationship between tooth size and stature in Pygmies, concluding that the relationships are generally statistically insignificant. This result would indicate that the relationship between body size and tooth size differs between Pygmy and the non-Pygmy populations represented in this case by the Fels collection of African Americans and by the Yuendumu collection of Australian Aborigines, for which some significant correlations were obtained. However, as in many other studies, Shea and Gomez measured molar diameters in individual specimens housed in collections and compared these dimensions with cranial measurements assumed to represent body size and with data on body size taken from the literature, in other words average size values for the population. Shea and Gomez (1988) is the only previous contribution that studied a pygmy population, however the relationship between tooth size and stature, i.e. measuring teeth and stature in the same individuals in a pygmy population, was never directly assessed.

Tooth size in Pygmies does not differ from that in other populations, and for some dimensions, teeth in Pygmies are in fact larger than in non-Pygmies (Romero et al 2018). This indicates an intraspecies relationship; since similar tooth dimensions correspond to very dissimilar body sizes, an absence of correlation between these two sets of variables would be expected for our species. However, we have seen that correlations do exist within some populations and that the degree of relationship among sexes varies depending on the 
population (Filipson and Godson 1963; Garn et al. 1968; Henderson and Corruccini 1976; Anderson et al. 1977; Wolpoff 1985). We have also mentioned that the relationship between body size and tooth dimensions in Pygmies was established using a number of disparate measurements; thus this relationship needs to be assessed more accurately. The aim of this study is therefore to analyze the relationship between tooth dimensions and body size in a pygmy population. We would expect the pygmy population, like other modern human populations, to present a certain number of correlations between tooth dimensions and body size. If this is confirmed, the relationship between these two sets of measurements would characterize our species even if the pattern is masked by wide differences in size among human populations. If it is not confirmed, the relationship between body size and tooth dimensions would follow a dissimilar pattern depending on populations: in our case study, the absence of correlations would probably be related to the particular somatic growth of Pygmies (see Ramirez Rozzi et al. 2015).

\section{Material and Methods}

African pygmies live in equatorial rain forests and grow to an average adult stature of $<155$ cm (Cavalli-Sforza 1986). They are semi-nomadic and share an economy based on hunting and gathering and a complex socioeconomic relationship with their farming neighbours. Pygmy populations are distributed across equatorial Africa in two main clusters. One is in East Africa (Ruanda, Uganda and Eastern DRC) and the Aka, Sua, Efe groups (also frequently called 'Mbuti') and the Batwa. The other cluster, in West Africa (Cameroon, Central Africa Republic, Congo, Gabon and Western DRC), includes the Kola, Bongo, Koya, Aka, Baka and Twa. Height and weight as well as the mesiodistal and buccolingual diameters of the permanent teeth $\left(\mathrm{I}^{1}-\mathrm{M}^{2}, \mathrm{I}_{1}-\mathrm{M}_{2}\right)$ were measured in the Baka pygmies, a semi-nomadic hunter-gatherer population living at Le Bosquet in South-East Cameroun. Baka females reach 
their adult stature at 18 years of age and males at 20 years of age (Ramirez Rozzi et al. 2015). The nuns established at Le Bosquet since the 1970s have kept systematic birth records since 1987, which were available to us. Only individuals who had reached their adult stature and were characterized by slight or moderate tooth wear (stages 1-3) based on Smith's (1984) occlusal surface wear stages, were included in the study. Full-mouth dental casts were obtained from adult Baka pygmies (45 females and 17 males) during fieldwork from 2007 to 2017. We are aware that the sample size is low and can introduce some bias in the results, but, in a similar way to previous works on this topic (e.g. Wolpoff 1985) or on fossils in which studies are based on few specimens, we are limited by what is available. Working with a Pygmy population is not trivial as this is a semi-nomadic group living in a forest away from villages and difficult to access. In those areas, birth records do not exist and the date of birth is most commonly ignored. Thus, the availability of birth records in Le Bosquet is a unique opportunity to study and track individuals who attained adulthood. It is not surprised that the only previous study on Pygmies was carried out on specimens housed at museum collections. It is worth noting that Shea and Gomez (1988) included in their work only 27 individuals whereas we include here 45 females and 17 males, more than twice the sample size of this pioneer study and similar to the sample size reported in Wolpoff's study (1985) on Yuendumu Australians (see Discussion). Since the populations are non-literate, all the participants provided verbal informed consent for the study, and the data were analyzed deidentified. The collection methods for a non-literate traditional population were reviewed and approved by the French National Centre for Scientific Research (CNRS), National Research Agency (ANR) and Research and Development Institute (IRD), and applied under an international agreement between the IRD and the Cameroon Ministry of Scientific Research and Technology (Ramirez Rozzi 2016). 
Weights were measured with electronic scales (Tanita) to the nearest $0.1 \mathrm{~kg}$ and height with a steel height gauge to the nearest $0.1 \mathrm{~cm}$. To identify if results from this study deviated from population averages, height and weight from the individuals under study were compared with values obtained in a previous study on the same population in which a growth model was built based on a longitudinal analysis over eight years that included nearly 550 individuals (Ramirez Rozzi et al. 2015). Maximum mesiodistal (MD) and buccolingual (BL) crown dimensions (in $\mathrm{mm}$ ) were obtained from casts for both $\mathrm{I}^{1}-\mathrm{M}^{2}$ and $\mathrm{I}_{1}-\mathrm{M}_{2}$. Teeth from left side were measured using a needle-point Helios-Preisser (Germany) digital caliper (0.01-mm precision) (Romero et al. 2018).

The mesiodistal (MD) and buccolingual (BL) tooth diameters were used to obtain an area (MD x BL) for each tooth. The diameters of all teeth were also used to obtain the geometric mean for each individual. Height and weight were used to calculate the BMI. Pearson's correlations of stature, weight and BMI with tooth diameters, areas and geometric means were obtained separately by sex.

Studies on the intraspecies relationship between tooth dimension and body size based on individual specimens housed in collections do not consider the possible influence of sexual dimorphism on correlations between these variables. This is also true for many other studies at interspecies level, particularly on fossil hominins. In order to illustrate changes in correlations when sexual dimorphism is not considered, analyzes were also performed with the sexes taken together and coefficients of determination were obtained. All analyzes were performed with SPSS.

\section{Results}

Descriptive statistics from this study are presented in table 1. Height and weight from individuals included in this study do not differ from those reported in a previous study based 
on a larger sample size of the same population (Ramirez Rozzi et al. 2015). Sexual dimorphism is found in stature and weight but not in the BMI (Table 1). Sexual dimorphism in tooth diameters was described in a previous study in which 11/14 diameters in upper teeth and 9/14 diameters in lower teeth are significant different between sexes at $\alpha=0.05$ (Romero et al. 2018). Correlations between tooth diameters and stature, weight and BMI are presented in tables 2, 3, and 4. Only two buccolingual diameters, $\mathbf{M}^{2}$ and $\mathrm{P}_{4}$, showed a significant correlation $(\mathrm{p}<0.05)$ with stature among Baka females. For males, none of the correlations between tooth diameters and stature were found to be significant. Only one diameter correlated with weight among Baka females $\left(\mathrm{C}^{-} \mathrm{MD}, \mathrm{p}<0.05\right)$ and only two among Baka males ( ${ }^{1} \mathrm{BL}$ and $\left.\mathrm{C}^{-} \mathrm{BL}, \mathrm{p}<0.05\right)$. BMI correlations were significant only in males. This included the MD diameter of $\mathrm{I}_{2}$ and the $\mathrm{BL}$ diameter of $\mathrm{C}^{-}(\mathrm{p}<0.05)$. About correlations between areas and stature (Table 5), weight (Table 6) and BMI (Table 7), the only tooth area presenting a correlation was that of the $\mathrm{M}^{2}(\mathrm{p}<0.05)$, with stature in females. Likewise, no significant correlations were found between geometric means and stature, weight or BMI among Baka pygmies (Fig. 1, Table 8).

Many correlations were found to be statistically significant when the sample was not divided by sex. In Figure 1, stature is correlated with the geometric mean $(p=0.002)$, but the coefficient of determination is extremely low $(\mathrm{r} 2=0.015)$, indicating only a slight relationship between the variables. The correlation between stature and the area of $\mathrm{M}^{2}$, the only dental variable found to be significantly correlated with stature among females, reaches a higher significant value when sexes are pooled $(\mathrm{p}<0.0001)($ Table 5), and the coefficient of determination raises at $r^{2}=0.239$. When sexes are pooled, five areas are correlated with stature at $\mathrm{p}<0.01$ and one at $\mathrm{p}<0.05$, and many tooth diameters are also correlated with stature; six at $\mathrm{p}<0.01$ and four at $\mathrm{p}<0.05$. Similar observations can be made for tooth diameters, areas and geometric means when compared with weight. 


\section{Discussion}

Studies on the relationship between tooth size and body size have revealed some significant correlations among tooth diameters and stature. Although there are few studies of this kind, they point to a relationship that seems to vary depending on sex. Studies on an Ohio population and on African Americans suggest more significant correlations among males than among females, but the opposite is true among Australian aborigines (Table 9). Some recent studies on Indian individuals (Yadav et al. 2016) showed significant correlations for all mesiodistal diameters of anterior teeth with stature. Surprisingly, Gupta et al. (2014) reported an absence of correlation in a study on anterior teeth also on Indian individuals. In the Baka pygmies, only two tooth crown diameters $(7 \%)$ were significantly correlated among females, while no diameters yielded significant correlations among males. The differences between the Baka and other populations is observed in the ratio between the sexes, even if Yuendumu females show a higher number of correlation than in males, Baka males do not show any significant correlation at all. But the more marked distinction concerns the very low number of significant correlations.

Sample size likely impacted the number of significant correlations between tooth dimensions and stature and thus the low number of significant relationships observed in the Baka could be considered a by-product of the reduced sample size. However, a detailed analysis of previous studies on the relationships between stature and tooth diameters shows that results of many works are based on the analysis of a sample size equivalent to that used in the Baka. Indeed, Wolpoff's (1985) study on Yuendumu population (Australian Aborigines) is based on the analysis of 45 females and 21 males (in some analyses the sample size is even lower). Therefore, the differences observed between the Baka and the Yuendumu cannot be attributed to differences in sample size. Garn et al. (1968) state that they have examined the 
relationship between stature and tooth diameters in 28 permanent teeth in 109 participants in the Fels study. However, in their table 1, the number of participants varies largely and the sample size, for instance, in the female $\mathrm{M}_{2}$ is 34 for the mesio-distal and 31 for the buccolingual diameters. Henderson and Corruccini (1976) study of American Blacks is imprecise, and the only mention of sample size is to be found in the results where they state that samples varied from 48 to 104 in males, and from 29 to 67 in females, depending on the availability of data. Others studies (e.g. Filipson and Godson 1963; Anderson et al. 1977; Yadav et al. 2016) limit their analysis to some tooth classes and even in these limited studies the sample size is small as in Gupta et al. (2014) in which 30 individuals were included by sex. Therefore, sample size can have an impact on the results but the detailed analysis of previous works reveals that in fact the sample size in the Baka is not much different than those in previous studies and that, with the exception of Wolpoff's report (1985), it is not clear if the analyses of all tooth classes were performed on the same individuals, as it was the case in our study.

The Baka are characterized by a reduced growth rate from birth to 2 years of age, after which it follows a pattern close to that observed in the lower percentiles for other groups (Ramirez Rozzi et al. 2015). Hence, the slow rate of growth during infancy is responsible for the short adult stature in the Baka. Also distinctive in the Baka is tooth formation, in which eruption occurs at an early age (Ramirez Rozzi 2016). This indicates a particular pattern of tooth development but does not affect tooth size (Romero et al. 2018). It would be tempting to say that the particular rate of growth during infancy probably affects the relationship between tooth dimensions and body size, but this relationship has not, as yet, been well established, still less understood (Park et al. 2012), in other human populations to give credence to any speculation about the relationship between somatic growth and tooth development in the Baka. Indeed, we have only limited knowledge about human genetic variants associated with 
common dental variations (Kimura et al. 2009, 2015; Lee et el. 2012; Park et al. 2012), and even less about genetic variations that may play a role in somatic growth and affect tooth dimensions. However, some studies have suggested that growth hormone secretion is associated with tooth eruption and maturation (Van Erum et al. 1998; Davidopoulus et al. 2017). It should be remembered here that the main function of growth hormones is to promote postnatal growth as part of the growth hormone-insulin like growth factor I axis (Rosenfeld 2003) and that the pygmy phenotype is attributed to a disturbance (at a currently unknown stage in growth) of this axis (Merimee et al. 1987). Recently, Hikita et al. (2018) found variants of the growth hormone receptor gene associated with changes in root and tooth length in some anterior teeth. However, because no clear genetic variant is known at present that could affect somatic growth and tooth dimensions, there is no developmental foundation for the correlations observed in some populations. Independently of this, however, the difference between the Baka and the other populations shows that variability in modern human populations also stems from the foundations of these correlations.

The Pygmy phenotype is largely considered as an adaptation to live in the forest (Hiernaux 1968; Perry and Domini 2009). The main discussion is focused on the kind of advantage such adaptation provides, in other words, if the pygmy phenotype accounts for a better balance in energy, a greater mobility or a more effective thermoregulation to live in the African equatorial forest. From this perspective, the selective pressure has strongly influenced body size. By contrast, this kind of pressure seems not to have affected tooth dimensions since the observed significant differences between the Baka and the Bantu populations result from larger teeth in the Baka (Romero et al. 2018). Therefore, the environment had an effect on stature but not on tooth dimensions. The low correlations between stature and tooth dimensions in the Baka are likely due to an environmental effect on the phenotype, without altering tooth size. 
One of the main goals in the first studies on the relationship between body size and tooth dimensions was to seek a foundation to infer body size from tooth size in fossil hominins (Garn and Lewis 1958). But the magnitude of the relationship between these two variables is so small that predictability is unreliable; therefore, inferring body size from tooth dimensions is unwarranted (see Wolpoff 1985). One aspect that makes the relationship between body size and tooth dimensions even more arbitrary is sexual dimorphism. When the analyzes are carried out for each sex, no correlation appears between tooth size and geometric mean; the same is true for almost all tooth areas and diameters. In contrast, when both sexes are taken together, size becomes correlated with the geometric mean $(\mathrm{P}<0.01)$ as well as with many other variables (Table 2). Although the correlations are non-significant when analyzed by sex, almost all the relationships are positive, meaning that areas or diameters increase with stature. Stature and tooth dimensions are larger in males than in females in the Baka (Romero et al. 2018). The regression curves when the sexes are analyzed together are not notably different to those obtained when the sexes are analyzed separately, but sexual dimorphism introduces a large enough bias to transform a non-significant relationship into a significant one. Similar results were observed for Yeundumu, when sexes are pulled together 26/32 relationships become significant (Wolpoff 1985). When the sexes are analyzed together, the regression curve becomes significant due to the higher values for males than females. This means that studies carried out without considering the sexes in the sample are probably revealing sexual differences rather than any kind of relationship between dental dimensions and body size. Sexual dimorphism in fossil hominins is a real challenge not only because of the small number of individuals, but also because the degree of sexual dimorphism probably varies among species. It is very likely that any analysis of correlations between tooth dimensions and body size (stature or any other skull or post-cranial measurement) requires prior knowledge of the degree of sexual dimorphism as the first step. 
Many studies (e.g. Wood 1979), specially the only previous work on Pygmies (Shea and Gomez 1988) use the term 'allometry' to refer to correlations. These studies, based on the concept developed by Huxley (1932) and Jolicoeur (1963), see allometry when a change in one trait is greater or less than a change in body size, generally stature. This concept is different to that suggested by Gould (1966) and Mosimann (1970), who consider that the terms 'allometry' and 'isometry' should be used when size is compared with shape. Godfrey and Sutherland (1995, 1996; Ramirez Rozzi 2000) have clearly explained the different interpretations that can be given of a result depending on the theoretical framework applied. Shea and Gomez (1988) reported some 'allometries' for Pygmies but they compare some traits against size (Huxley-Jolicoeur framework), use cranial measurements as proxies for body size and do not use any proxy for shape. In other words, their method did not allow to assess allometry. Further, they did not distinguish between sexes and thus the few relationships they found between stature and tooth dimeters probably results from analysing sexes pulled together The few significant correlations between tooth diameters and stature and the lack of any significant correlation of area or geometric mean with stature in our analysis mean that changes in body size are accompanied by a random variation in tooth dimensions in the Baka pygmies.

To summarize, relationships between body size and tooth dimensions are almost nonexistent in the Baka pygmies, in contrast with other populations in which these two aspects show some degree of relationship. This peculiarity in the Baka would result from environmental effects on stature as an adaptation to live in the forest. Our analysis also shows that the results are affected when sexual dimorphism is not taken into account, implying that proposals from studies in which the sexes are analyzed together have to be considered with caution. 


\section{Acknowledgements}

The authors thank X. Garde, B. Bordage and all the staff at IRD Yaounde for their logistical support, as well as the nuns at the Le Bosquet Mission for their kind hospitality. Special thanks are due to P. Kalo and J. B. Etoa for their assistance and friendship, and to all the Baka people involved in the field studies for their help and hospitality and whose participation made this research possible. We are also grateful to A. Froment, L. Maget, and A. Perez-Perez for their helpful comments. Research funded by PICS 07492 MAMIBAKA, Wenner-Gren Foundation (grant \#7819), National Geographic Society (grant \#8863-10), and Agence National de la Recherche (ANR-11-BSV7-0011) to FRR and Spanish Ministerio de Economía y Competitividad (grant \# CGL2011-22999 and \# CGL2014-52611-C2-1-P) to AR.

\section{Declaration of interest}

The authors report no conflict of interest 


\section{References}

Anderson DL, Thompson GW. 1973. Interrelationships and sex differences of dental and skeletal measurements. J Dent Res. 52: 431-438.

Anderson DL, Thompson GW, Popovich F. 1977. Tooth, chin, bone and body size correlations. Am J Phys Anthropol. 46: 7-12.

Cavalli-Sforza, L. 1886. African Pygmies. New York: Academic Press.

Cole TJ, Mori H. 2017. Fifty years of child height and weight in Japan and South Korea: Contrasting secular trend patterns analyzed by SITAR. Am J Hum Biol. 30(1):e23054.

Davidopoulou S, Chatzigianni A. 2017. Craniofacial morphology and dental maturity in children with reduced somatic growth of different aetiology and the effect of growth hormone treatment. Prog Orthod. 18:10.

Filipson R, Goldson L. 1963. Correlation between tooth width, width of the head, length of the head, and stature. Acta Odont Scand. 21:359-365.

Garn SM, Lewis AB. 1958. Tooth size, body size, and "giant" fossil man. Am Anthropol. 60:874-880.

Garn SM, Lewis AB, Kerewsky RS. 1968. The magnitude and implications of the relationship between tooth size and body size. Arch oral Biol. 13:129-131.

Godfrey LR, Sutherland MR. 1995. What's growth got to do with it? Process and product in the evolution of ontogeny. J Hum Evol. 29:405-431.

Godfrey LR, Sutherland MR. 1996. The paradox of peramorphic paedomorphosis: heterochrony and human evolution. Am J Phys Anthropol. 99:17-42.

Gould SJ. 1966. Allometry and size in ontogeny and phylogeny. Biol Reviews 4(1):587640. 
Gupta A, Kumar K, Shetty DC, Wadhwan V, Jain A, Khanna KS. 2014. Stature and gender determination and their correlation using odontometry and skull anthropometry. J Forensic Dent Sc. 6(2), 101-06.

Henderson AM, Corruccini RS. 1976. Relationship between tooth size and body size in American Blacks. Dent Res. 55 :94-96.

Hiernaux J. 1968. La diversité humaine en Afrique subsaharienne. Recherches biologiques. Bruxelles: Editions de l'Institut de Sociologie.

Hikita Y, Yamaguchi T, Tomita D, Adel M, Nakawaki T, Katayama K, Maki K, Kimura R. 2018. Growth hormone receptor gene is related to root length and tooth length in human teeth. Angle Orthodontist, doi: 10.2319/092917-659.1

Huxley JS. 1932. Problems of relative growth. London: Methuen.

Jolicoeur P. 1963. The multivariate generalization of the allometry equation. Biometrics. 19:497- 499.

Johnson W, Choh AC, Soloway LE, Czerwinski SA, Towne B, Demerath EW. 2011. Eighty-year trends in infant weight and length growth: the Fels Longitudinal Study. J Pediatr. 160(5):762-8.

Kimura R, Yamaguchi T, Takeda M, et al. 2009. A common variation in EDAR is a genetic determinant of shovel-shaped incisors. Am J Hum Gen. 85:528-535.

Kimura R, Watanabe C, Kawaguchi A, et al. 2015. Common polymorphisms in WNT10A affect tooth morphology as well as hair shape. Hum Mol Genet. 24:2673-2680.

Lavelle CLB. 1974. Relationship between tooth and skull size. J Dent Res. 53: 1301.

Lavelle CLB. 1977. Relationship between tooth and long bone size. Am J Phys Anthropol. $46: 423-426$. 
Lee WC, Yamaguchi T, Watanabe C, et al. 2012. Association of common PAX9 variants with permanent tooth size variation in non-syndromic East Asian populations. J Hum Gen. $57: 654-659$.

Merimee TJ, Zapf J, Hewlett B, Cavalli-Sforza LL. 1987. Insulin-like growth factor in Pygmies. The role of puberty in determining final stature. N. Eng. J. Med. 316:906-911. Mosimann JE. 1970. Size allometry: size and shape variables with characterizations of the lognormal and generalized gamma distributions. J Am Stat Ass. 65:930-945.

Park JH, Yamaguchi T, Watanabe C, et al. 2012. Effects of an Asian-specific nonsynonymous EDAR variant on multiple dental traits. J Hum Gen. 57:508-514.

Perry GH, Dominy NJ. 2009. Evolution of the human pygmy phenotype. Trends Ecol. Evol. 24:218-225.

Ramirez Rozzi FV. 2000. Hétérochronies : états des lieux. Primatologie. 3:479-512.

Ramírez Rozzi FV. 2016. Diversity in tooth eruption and life history in humans: illustration from a Pygmy population. Scientific Reports | 6:27405 | DOI: 10.1038/srep2740. Ramírez Rozzi FV, Koudou Y, Froment A, Le Bouc Y, Botton J. 2015. Growth pattern from birth to adulthood in African pygmies of known age. Nature Communications 6, 7672; doi:10.1038/ncomms8672

Romero A, Ramírez Rozzi FV, Pérez-Pérez A. 2018. Dental size variability in Central African Pygmy hunter-gatherers and Bantu-speaking farmers. Am J Phys Anthropol. 166:671681.

Rosenfeld RG. 2003. Insulin-like growth factors and the basis of growth. N Eng J Med. 349:2184-2186.

Shea BT, Gomez AM. 1988. Tooth scaling and evolutionary dwarfism: An investigation of allometry in human Pygmies. Am J Phys Anthropol. 77:117-132. 
Smith BH. 1984. Patterns of molar wear in hunter-gatherers and agriculturalists. Am J Phys Anthropol. 63:39-56.

Steudel K. 1982. Patterns of intraspecific and interspecific allometry in Old World Primates. Am J Phys Anthropol. 59:419-430.

Ungarn P. 2014. Dental allometry in mammals: a retrospective. Ann Zool Fennici. 51:177187.

Van Erum R, Mulier G, Carels C, de Zegher F. 1998. Craniofacial growth and dental maturation in short children born small for gestational age: effect of growth hormone treatment. Own observations and review of the literature. Horm Res. 50:141-146.

Vinyard C J, Hanna J. 2005. Molar scaling in strepsirrhine primates. J Hum Evol. 49:241269.

Wolpoff MH. 1973. Posterior tooth size, body size, and diet in South African gracile australopithecines. Am J Phys Anthropol. 39:375-394.

Wolpoff MH. 1985. Tooth size-body size scaling in a human population, theory and practice of an allometric analysis. In W.L. Jungers (Ed.), Size and scaling in primate biology (pp. 273-318). New York: Plenum.

Wood BA. 1979. An analysis of tooth and body size relationships in five primate taxa. Folia Primatologica. 31:187-211.

Yadav AB, Yadav SK, Kedia NB, Singh AK. 2016. An odontometric approach for estimation of stature in Indians: cross- sectional analysis. Journal of Clinical and Diagnostic Research. 10:ZC24-ZC26. 
Table 1: Height and weight by sexes

t-test pop

$t$-test sx

\begin{tabular}{lccccccccc} 
Females & Average & $\mathbf{n}$ & sd & ES & Average (sd) $^{\mathbf{1}}$ & $\mathbf{t}$ & $\mathbf{p}$ & $\mathbf{t}$ & $\mathbf{p}$ \\
\hline Height & 147.55 & 45 & 5.73 & 0.85 & $146.7(4.7)$ & 0.994 & 0.326 & $-5,356$ & 0,0001 \\
Weight & 44.35 & 45 & 6.19 & 0.92 & $45.9(4.8)$ & -1.68 & 0.099 & $-3,355$ & 0,001 \\
BMI & 20.38 & 45 & 2.62 & 0.39 & & & & $-0,693$ & 0,491 \\
Males & & & & & & & & & \\
\cline { 1 - 3 } Height & 155.87 & 17 & 4.64 & 1.13 & $153.5(6.2)$ & 2.11 & 0.051 & & \\
Weight & 51.04 & 17 & 8.88 & 2.15 & $52.9(6.6)$ & -0.863 & 0.401 & & \\
BMI & 20.92 & 17 & 2.96 & 0.72 & & & & &
\end{tabular}

1: average values and standard deviation from Ramirez Rozzi et al. (2015).

$t$-test pop: comparison between individuals included in this study and data from Ramirez Rozzi et al. (2015).

$t$-test sx: comparison between sexes (this study). 
Table 2: Correlations between tooth diameters and stature

\begin{tabular}{|c|c|c|c|c|c|c|}
\hline \multirow[b]{2}{*}{ MD } & \multicolumn{2}{|c|}{ Females } & \multicolumn{2}{|c|}{ Males } & \multicolumn{2}{|c|}{ All } \\
\hline & $r$ & $p$ & $r$ & $p$ & $r$ & $p$ \\
\hline $\mathrm{I}^{1}$ & 0.02 & 0.896 & 0.041 & 0.877 & 0.142 & 0.27 \\
\hline $\mathrm{I}^{2}$ & 0.167 & 0.273 & -0.199 & 0.444 & 0.204 & 0.111 \\
\hline $\mathrm{C}^{\mathrm{s}}$ & 0.261 & 0.083 & 0.048 & 0.854 & 0.392 & 0.002 \\
\hline $\mathrm{P}^{3}$ & 0.073 & 0.631 & 0.269 & 0.296 & 0.096 & 0.456 \\
\hline $\mathrm{P}^{4}$ & 0.141 & 0.355 & -0.039 & 0.881 & 0.164 & 0.201 \\
\hline $\mathbf{M}^{1}$ & -0.088 & 0.565 & 0.277 & 0.282 & 0.197 & 0.125 \\
\hline $\mathrm{M}^{2}$ & 0.241 & 0.11 & 0.128 & 0.624 & 0.436 & 0.001 \\
\hline $\mathrm{I}_{1}$ & -0.115 & 0.452 & 0.038 & 0.886 & -0.048 & 0.709 \\
\hline $\mathrm{I}_{2}$ & 0.103 & 0.502 & -0.134 & 0.609 & 0.105 & 0.418 \\
\hline $\mathrm{C}_{\mathrm{s}}$ & 0.084 & 0.585 & 0.158 & 0.546 & 0.301 & 0.017 \\
\hline $\mathrm{P}_{3}$ & -0.107 & 0.485 & 0.012 & 0.963 & -0.088 & 0.498 \\
\hline $\mathrm{P}_{4}$ & -0.057 & 0.71 & -0.087 & 0.74 & 0.014 & 0.912 \\
\hline $\mathbf{M}_{1}$ & 0.102 & 0.506 & 0.14 & 0.592 & 0.241 & 0.059 \\
\hline $\mathrm{M}_{2}$ & 0.029 & 0.852 & 0.175 & 0.501 & 0.17 & 0.187 \\
\hline $\mathrm{BL}$ & & & & & & \\
\hline $\mathrm{I}^{1}$ & 0.174 & 0.252 & 0.45 & 0.07 & 0.403 & 0.001 \\
\hline $\mathrm{I}^{2}$ & 0.197 & 0.194 & -0.096 & 0.713 & 0.326 & 0.01 \\
\hline $\mathrm{C}^{\mathrm{s}}$ & 0.234 & 0.122 & 0.111 & 0.67 & 0.443 & 0.001 \\
\hline $\mathrm{P}^{3}$ & -0.073 & 0.361 & 0.249 & 0.335 & 0.08 & 0.534 \\
\hline $\mathrm{P}^{4}$ & -0.086 & 0.572 & 0.251 & 0.332 & 0.061 & 0.64 \\
\hline $\mathbf{M}^{1}$ & -0.173 & 0.254 & 0.155 & 0.552 & 0.032 & 0.806 \\
\hline $\mathrm{M}^{2}$ & 0.354 & 0.017 & 0.271 & 0.293 & 0.421 & 0.001 \\
\hline $\mathrm{I}_{1}$ & -0.114 & 0.457 & 0.462 & 0.062 & 0.142 & 0.27 \\
\hline $\mathrm{I}_{2}$ & 0.101 & 0.509 & 0.101 & 0.698 & 0.267 & 0.036 \\
\hline $\mathrm{C}_{\mathrm{s}}$ & 0.278 & 0.064 & 0.018 & 0.945 & 0.459 & 0.001 \\
\hline $\mathrm{P}_{3}$ & 0.273 & 0.07 & 0.065 & 0.806 & 0.207 & 0.106 \\
\hline $\mathrm{P}_{4}$ & 0.373 & 0.012 & -0.087 & 0.739 & 0.257 & 0.044 \\
\hline $\mathbf{M}_{1}$ & 0.094 & 0.539 & -0.009 & 0.972 & 0.151 & 0.242 \\
\hline $\mathrm{M}_{2}$ & -0.186 & 0.222 & 0.207 & 0.425 & 0.134 & 0.298 \\
\hline
\end{tabular}


Table 3: Correlations between tooth diameters and weight

\begin{tabular}{|c|c|c|c|c|c|c|}
\hline \multirow[b]{2}{*}{ MD } & \multicolumn{2}{|c|}{ Females } & \multicolumn{2}{|c|}{ Males } & \multicolumn{2}{|c|}{ All } \\
\hline & $r$ & $p$ & $r$ & $p$ & $r$ & $p$ \\
\hline $\mathrm{I}^{1}$ & 0.033 & 0.831 & -0.009 & 0.974 & 0.091 & 0.481 \\
\hline $\mathrm{I}^{2}$ & 0.214 & 0.157 & -0.184 & 0.48 & 0.179 & 0.164 \\
\hline $\mathrm{C}^{\mathrm{s}}$ & 0.328 & 0.028 & 0.075 & 0.774 & 0.366 & 0.003 \\
\hline $\mathrm{P}^{3}$ & 0.161 & 0.291 & 0.32 & 0.21 & 0.2 & 0.119 \\
\hline $\mathrm{P}^{4}$ & 0.051 & 0.741 & 0.208 & 0.424 & 0.144 & 0.265 \\
\hline $\mathbf{M}^{1}$ & 0.056 & 0.717 & 0.27 & 0.294 & 0.235 & 0.066 \\
\hline $\mathrm{M}^{2}$ & 0.132 & 0.388 & 0.236 & 0.363 & 0.305 & 0.016 \\
\hline $\mathrm{I}_{1}$ & -0.042 & 0.783 & 0.014 & 0.958 & -0.015 & 0.911 \\
\hline $\mathrm{I}_{2}$ & 0.202 & 0.182 & -0.477 & 0.053 & 0.065 & 0.617 \\
\hline $\mathrm{C}_{\mathrm{s}}$ & 0.166 & 0.257 & 0.17 & 0.515 & 0.283 & 0.026 \\
\hline $\mathrm{P}_{3}$ & 0.167 & 0.273 & 0.112 & 0.669 & 0.129 & 0.316 \\
\hline $\mathrm{P}_{4}$ & 0.204 & 0.18 & 0.193 & 0.457 & 0.222 & 0.083 \\
\hline $\mathrm{M}_{1}$ & -0.104 & 0.498 & 0.052 & 0.843 & 0.056 & 0.667 \\
\hline $\mathrm{M}_{2}$ & 0.138 & 0.367 & 0.236 & 0.363 & 0.228 & 0.075 \\
\hline \multicolumn{7}{|l|}{ BL } \\
\hline $\mathrm{I}^{1}$ & -0.042 & 0.783 & 0.515 & 0.034 & 0.268 & 0.035 \\
\hline $\mathrm{I}^{2}$ & 0.15 & 0.324 & 0.243 & 0.348 & 0.262 & 0.039 \\
\hline $\mathrm{C}^{\mathrm{s}}$ & 0.174 & 0.254 & 0.546 & 0.023 & 0.392 & 0.002 \\
\hline $\mathrm{P}^{3}$ & 0.221 & 0.144 & 0.217 & 0.402 & 0.256 & 0.045 \\
\hline $\mathrm{P}^{4}$ & 0.101 & 0.509 & 0.235 & 0.364 & 0.176 & 0.172 \\
\hline $\mathrm{M}^{1}$ & -0.018 & 0.904 & 0.011 & 0.967 & 0.065 & 0.618 \\
\hline $\mathrm{M}^{2}$ & 0.22 & 0.146 & 0.246 & 0.342 & 0.305 & 0.016 \\
\hline $\mathrm{I}_{1}$ & 0.088 & 0.566 & 0.132 & 0.614 & 0.172 & 0.182 \\
\hline $\mathrm{I}_{2}$ & 0.09 & 0.556 & 0.108 & 0.679 & 0.201 & 0.117 \\
\hline $\mathrm{C}_{\mathrm{s}}$ & 0.168 & 0.269 & 0.218 & 0.401 & 0.342 & 0.007 \\
\hline $\mathrm{P}_{3}$ & 0.021 & 0.892 & 0.025 & 0.925 & 0.043 & 0.743 \\
\hline $\mathrm{P}_{4}$ & 0.029 & 0.849 & -0.094 & 0.719 & 0.018 & 0.893 \\
\hline $\mathrm{M}_{1}$ & -0.11 & 0.471 & -0.212 & 0.414 & -0.067 & 0.606 \\
\hline $\mathrm{M}_{2}$ & 0.144 & 0.344 & 0.033 & 0.9 & 0.22 & 0.086 \\
\hline
\end{tabular}


Table 4: Correlations between tooth diameters and BMI

\begin{tabular}{|c|c|c|c|c|c|c|}
\hline \multirow[b]{2}{*}{ MD } & \multicolumn{2}{|c|}{ Females } & \multicolumn{2}{|c|}{ Males } & \multicolumn{2}{|c|}{ All } \\
\hline & $r$ & $p$ & $r$ & $p$ & $\boldsymbol{r}$ & $p$ \\
\hline $\mathrm{I}^{1}$ & 0.026 & 0.867 & -0.027 & 0.917 & 0.022 & 0.863 \\
\hline $\mathrm{I}^{2}$ & 0.123 & 0.419 & -0.145 & 0.578 & 0.086 & 0.504 \\
\hline $\mathrm{C}^{\mathrm{s}}$ & 0.207 & 0.172 & 0.075 & 0.774 & 0.192 & 0.135 \\
\hline $\mathrm{P}^{3}$ & 0.133 & 0.384 & 0.284 & 0.269 & 0.171 & 0.186 \\
\hline $\mathrm{P}^{4}$ & -0.008 & 0.958 & 0.266 & 0.303 & 0.069 & 0.593 \\
\hline $\mathrm{M}^{1}$ & 0.103 & 0.503 & 0.223 & 0.39 & 0.154 & 0.233 \\
\hline $\mathrm{M}^{2}$ & 0.024 & 0.877 & 0.234 & 0.366 & 0.098 & 0.449 \\
\hline $\mathrm{I}_{1}$ & 0.01 & 0.947 & 0.003 & 0.992 & 0.011 & 0.933 \\
\hline $\mathrm{I}_{2}$ & 0.16 & 0.293 & -0.53 & 0.029 & 0.014 & 0.915 \\
\hline $\mathrm{C}_{\mathrm{s}}$ & 0.13 & 0.396 & 0.134 & 0.607 & 0.15 & 0.246 \\
\hline $\mathrm{P}_{3}$ & 0.224 & 0.139 & 0.135 & 0.605 & 0.196 & 0.127 \\
\hline $\mathrm{P}_{4}$ & 0.227 & 0.134 & 0.268 & 0.299 & 0.242 & 0.058 \\
\hline $\mathrm{M}_{1}$ & -0.152 & 0.32 & 0.009 & 0.972 & -0.073 & 0.571 \\
\hline $\mathrm{M}_{2}$ & 0.119 & 0.438 & 0.228 & 0.378 & 0.161 & 0.211 \\
\hline \multicolumn{7}{|l|}{ BL } \\
\hline $\mathrm{I}^{1}$ & -0.121 & 0.429 & 0.452 & 0.069 & 0.074 & 0.567 \\
\hline $\mathrm{I}^{2}$ & 0.043 & 0.778 & 0.328 & 0.199 & 0.112 & 0.386 \\
\hline $\mathrm{C}^{\mathrm{s}}$ & 0.066 & 0.668 & 0.62 & 0.008 & 0.192 & 0.135 \\
\hline $\mathrm{P}^{3}$ & 0.264 & 0.08 & 0.165 & 0.526 & 0.243 & 0.057 \\
\hline $\mathrm{P}^{4}$ & 0.149 & 0.328 & 0.18 & 0.49 & 0.164 & 0.202 \\
\hline $\mathbf{M}^{1}$ & 0.07 & 0.649 & -0.051 & 0.845 & 0.055 & 0.671 \\
\hline $\mathrm{M}^{2}$ & 0.056 & 0.716 & 0.184 & 0.479 & 0.107 & 0.407 \\
\hline $\mathrm{I}_{1}$ & 0.139 & 0.362 & -0.016 & 0.952 & 0.113 & 0.381 \\
\hline $\mathrm{I}_{2}$ & 0.041 & 0.787 & 0.087 & 0.741 & 0.076 & 0.555 \\
\hline $\mathrm{C}_{\mathrm{s}}$ & 0.04 & 0.796 & 0.259 & 0.315 & 0.127 & 0.327 \\
\hline $\mathrm{P}_{3}$ & -0.107 & 0.485 & 0.005 & 0.986 & -0.069 & 0.593 \\
\hline $\mathrm{P}_{4}$ & -0.15 & 0.326 & -0.079 & 0.763 & -0.126 & 0.331 \\
\hline $\mathrm{M}_{1}$ & -0.152 & 0.318 & -0.249 & 0.335 & -0.161 & 0.212 \\
\hline $\mathrm{M}_{2}$ & 0.238 & 0.116 & -0.042 & 0.874 & 0.173 & 0.18 \\
\hline
\end{tabular}


Table 5: Correlations between tooth areas and stature

\begin{tabular}{c|cc|cc|cc|} 
& \multicolumn{2}{|c|}{ Females } & \multicolumn{2}{|c|}{ Males } & \multicolumn{2}{|c|}{ All } \\
\cline { 2 - 7 } & $\boldsymbol{r}$ & $\boldsymbol{p}$ & $\boldsymbol{r}$ & $\boldsymbol{p}$ & $\boldsymbol{r}$ & $\boldsymbol{p}$ \\
\hline $\mathrm{I}^{1}$ & 0.125 & 0.413 & 0.327 & 0.2 & 0.364 & $\mathbf{0 . 0 0 4}$ \\
$\mathrm{I}^{2}$ & 0.248 & 0.1 & -0.167 & 0.521 & 0.329 & $\mathbf{0 . 0 0 9}$ \\
$\mathrm{C}^{\mathrm{s}}$ & 0.261 & 0.084 & 0.093 & 0.722 & 0.463 & $\mathbf{0 . 0 0 1}$ \\
$\mathrm{P}^{3}$ & -0.004 & 0.977 & 0.279 & 0.278 & 0.099 & 0.443 \\
$\mathrm{P}^{4}$ & 0.02 & 0.898 & 0.141 & 0.589 & 0.123 & 0.339 \\
$\mathrm{M}^{1}$ & -0.168 & 0.27 & 0.239 & 0.355 & 0.126 & 0.328 \\
$\mathrm{M}^{2}$ & 0.332 & $\mathbf{0 . 0 2 6}$ & 0.225 & 0.385 & 0.489 & $\mathbf{0 . 0 0 1}$ \\
& & & & & & \\
& $\boldsymbol{r}$ & $\boldsymbol{p}$ & $\boldsymbol{r}$ & $\boldsymbol{p}$ & $\boldsymbol{r}$ & $\boldsymbol{p}$ \\
\hline $\mathrm{I}_{1}$ & -0.142 & 0.353 & 0.328 & 0.199 & 0.069 & 0.592 \\
$\mathrm{I}_{2}$ & 0.12 & 0.432 & 0.03 & 0.91 & 0.253 & $\mathbf{0 . 0 4 7}$ \\
$\mathrm{C}_{\mathrm{s}}$ & 0.22 & 0.146 & 0.087 & 0.74 & 0.45 & $\mathbf{0 . 0 0 1}$ \\
$\mathrm{P}_{3}$ & 0.08 & 0.6 & 0.038 & 0.885 & 0.066 & 0.608 \\
$\mathrm{P}_{4}$ & 0.217 & 0.153 & -0.098 & 0.707 & 0.176 & 0.172 \\
$\mathrm{M}_{1}$ & 0.103 & 0.499 & 0.055 & 0.833 & 0.213 & 0.096 \\
$\mathrm{M}_{2}$ & -0.077 & 0.617 & 0.199 & 0.445 & 0.166 & 0.197
\end{tabular}

Table 6: Correlations between tooth areas and weight

\begin{tabular}{c|ll|ll|ll|} 
& \multicolumn{2}{|c|}{ Females } & \multicolumn{2}{|c|}{ Males } & \multicolumn{2}{c|}{ All } \\
\cline { 2 - 6 } & \multicolumn{1}{|c}{$\boldsymbol{r}$} & $\boldsymbol{p}$ & $\boldsymbol{r}$ & \multicolumn{1}{c|}{$\boldsymbol{p}$} & \multicolumn{1}{c|}{$\boldsymbol{r}$} & \multicolumn{1}{c|}{$\boldsymbol{p}$} \\
\hline $\mathrm{I}^{1}$ & -0.014 & 0.925 & 0.344 & 0.176 & 0.24 & 0.06 \\
$\mathrm{I}^{2}$ & 0.214 & 0.158 & 0.073 & 0.779 & 0.272 & $\mathbf{0 . 0 3 3}$ \\
$\mathrm{C}^{\mathrm{S}}$ & 0.264 & 0.08 & 0.399 & 0.113 & 0.418 & $\mathbf{0 . 0 0 1}$ \\
$\mathrm{P}^{3}$ & 0.21 & 0.166 & 0.293 & 0.254 & 0.25 & $\mathbf{0 . 0 5}$ \\
$\mathrm{P}^{4}$ & 0.081 & 0.597 & 0.24 & 0.353 & 0.173 & 0.178 \\
$\mathrm{M}^{1}$ & 0.017 & 0.909 & 0.154 & 0.555 & 0.167 & 0.195 \\
$\mathrm{M}^{2}$ & 0.208 & 0.169 & 0.253 & 0.327 & 0.348 & $\mathbf{0 . 0 0 6}$ \\
& & & & & & \\
& $\boldsymbol{r}$ & $\boldsymbol{p}$ & $\boldsymbol{r}$ & $\boldsymbol{p}$ & $\boldsymbol{r}$ & $\boldsymbol{p}$ \\
\hline $\mathrm{I}_{1}$ & 0.033 & 0.831 & 0.099 & 0.706 & 0.111 & 0.392 \\
$\mathrm{I}_{2}$ & 0.183 & 0.23 & -0.165 & 0.526 & 0.183 & 0.155 \\
$\mathrm{C}_{\mathrm{s}}$ & 0.203 & 0.181 & 0.224 & 0.387 & 0.361 & $\mathbf{0 . 0 0 4}$ \\
$\mathrm{P}_{3}$ & 0.117 & 0.442 & 0.08 & 0.76 & 0.105 & 0.419 \\
$\mathrm{P}_{4}$ & 0.136 & 0.375 & 0.038 & 0.884 & 0.134 & 0.299 \\
$\mathrm{M}_{1}$ & -0.125 & 0.414 & -0.1 & 0.702 & -0.017 & 0.895 \\
$\mathrm{M}_{2}$ & 0.153 & 0.317 & 0.153 & 0.559 & 0.244 & 0.055
\end{tabular}


Table 7: Correlations between tooth areas and BMI

\begin{tabular}{c|cc|cc|cc|} 
& \multicolumn{2}{|c|}{ Females } & \multicolumn{2}{c|}{ Males } & \multicolumn{2}{c|}{ All } \\
\cline { 2 - 7 } & $\boldsymbol{r}$ & $\boldsymbol{p}$ & $\boldsymbol{r}$ & $\boldsymbol{p}$ & $\boldsymbol{r}$ & $\boldsymbol{p}$ \\
\hline $\mathrm{I}^{1}$ & -0.076 & 0.62 & 0.289 & 0.261 & 0.065 & 0.616 \\
$\mathrm{I}^{2}$ & 0.093 & 0.542 & 0.156 & 0.551 & 0.121 & 0.349 \\
$\mathrm{C}^{\mathrm{s}}$ & 0.137 & 0.368 & 0.448 & 0.071 & 0.21 & 0.101 \\
$\mathrm{P}^{3}$ & 0.213 & 0.16 & 0.245 & 0.343 & 0.227 & 0.076 \\
$\mathrm{P}^{4}$ & 0.072 & 0.64 & 0.236 & 0.361 & 0.126 & 0.33 \\
$\mathrm{M}^{1}$ & 0.1 & 0.513 & 0.093 & 0.723 & 0.117 & 0.365 \\
$\mathrm{M}^{2}$ & 0.047 & 0.761 & 0.218 & 0.4 & 0.116 & 0.368 \\
& & & & & & \\
& $\boldsymbol{r}$ & $\boldsymbol{p}$ & $\boldsymbol{r}$ & $\boldsymbol{p}$ & $\boldsymbol{r}$ & $\boldsymbol{p}$ \\
\hline $\mathrm{I}_{1}$ & 0.102 & 0.503 & -0.009 & 0.971 & 0.086 & 0.508 \\
$\mathrm{I}_{2}$ & 0.125 & 0.414 & -0.212 & 0.413 & 0.063 & 0.625 \\
$\mathrm{C}_{\mathrm{s}}$ & 0.096 & 0.531 & 0.238 & 0.357 & 0.154 & 0.233 \\
$\mathrm{P}_{3}$ & 0.079 & 0.608 & 0.082 & 0.753 & 0.08 & 0.534 \\
$\mathrm{P}_{4}$ & 0.03 & 0.845 & 0.085 & 0.745 & 0.052 & 0.689 \\
$\mathrm{M}_{1}$ & -0.176 & 0.247 & -0.144 & 0.582 & -0.14 & 0.277 \\
$\mathrm{M}_{2}$ & 0.191 & 0.209 & 0.107 & 0.683 & 0.182 & 0.156
\end{tabular}

Table 8: Correlations between geometric mean with stature, weight and BMI

\begin{tabular}{c|cc|cc|cc|} 
GeomMean & \multicolumn{2}{|c|}{ Females } & \multicolumn{2}{|c|}{ Males } & \multicolumn{2}{c|}{ All } \\
\cline { 2 - 7 } & $r$ & $p$ & $r$ & $p$ & $r$ & $p$ \\
\hline Stature & 0.044 & 0.776 & 0.2 & 0.44 & 0.313 & $\mathbf{0 . 0 1 3}$ \\
Weight & 0.205 & 0.178 & 0.227 & 0.38 & 0.335 & $\mathbf{0 . 0 0 8}$ \\
BMI & 0.184 & 0.226 & 0.197 & 0.448 & 0.201 & 0.117
\end{tabular}


Table 9: Correlations of tooth diameters with stature in modern human populations

\begin{tabular}{|c|c|c|c|c|c|c|c|c|}
\hline \multicolumn{9}{|c|}{ Males } \\
\hline \multicolumn{3}{|c|}{$\mathrm{MD}$} & \multirow[b]{2}{*}{$\mathrm{AmW}^{\mathrm{c}}$} & \multirow[b]{2}{*}{$A m A f^{d}$} & \multicolumn{2}{|l|}{$\mathrm{BL}$} & \multirow[b]{2}{*}{$\mathrm{AmW}^{\mathrm{c}}$} & \multirow[b]{2}{*}{$A m A f^{d}$} \\
\hline Tooth & $\mathrm{Baka}^{\mathrm{a}}$ & AustAb $b^{b}$ & & & $\mathrm{Baka}^{\mathrm{a}}$ & AustAb $b^{b}$ & & \\
\hline $\mathrm{I}^{1}$ & 0.04 & 0.35 & 0.02 & 0.32 & 0.45 & 0.31 & 0.13 & 0.32 \\
\hline $\mathrm{I}^{2}$ & -0.19 & 0.26 & 0.20 & 0.22 & -0.09 & 0.19 & 0.31 & 0.27 \\
\hline $\mathrm{C}^{\mathrm{s}}$ & 0.04 & 0.40 & 0.30 & 0.33 & 0.11 & 0.08 & 0.04 & 0.17 \\
\hline $\mathrm{P}^{3}$ & 0.27 & 0.21 & 0.18 & 0.19 & 0.25 & 0.36 & 0.16 & 0.24 \\
\hline $\mathrm{P}^{4}$ & -0.04 & 0.01 & 0.23 & 0.22 & 0.25 & 0.26 & 0.29 & 0.13 \\
\hline $\mathrm{M}^{1}$ & 0.27 & 0.07 & 0.27 & 0.28 & 0.15 & 0.25 & 0.18 & 0.11 \\
\hline $\mathbf{M}^{2}$ & 0.12 & 0.00 & 0.27 & 0.22 & 0.27 & 0.10 & 0.50 & 0.18 \\
\hline $\mathrm{I}_{1}$ & 0.03 & 0.25 & 0.24 & 0.25 & 0.46 & 0.18 & 0.16 & 0.25 \\
\hline $\mathrm{I}_{2}$ & -0.13 & 0.29 & 0.11 & 0.26 & 0.10 & 0.24 & 0.09 & 0.32 \\
\hline $\mathrm{C}_{\mathrm{s}}$ & 0.15 & 0.38 & 0.11 & 0.22 & 0.01 & 0.11 & 0.17 & 0.27 \\
\hline $\mathrm{P}_{3}$ & 0.01 & 0.05 & 0.37 & 0.28 & 0.06 & 0.18 & 0.23 & 0.19 \\
\hline $\mathrm{P}_{4}$ & -0.08 & 0.14 & 0.05 & 0.24 & -0.08 & 0.13 & 0.22 & 0.15 \\
\hline $\mathrm{M}_{1}$ & 0.14 & -0.16 & 0.01 & 0.37 & -0.01 & 0.30 & 0.05 & 0.24 \\
\hline $\mathrm{M}_{2}$ & 0.17 & 0.24 & 0.19 & 0.18 & 0.20 & 0.12 & 0.25 & 0.22 \\
\hline ratio & $0 / 14$ & $3 / 14$ & $6 / 14$ & $11 / 14$ & $0 / 14$ & $1 / 14$ & $6 / 14$ & $9 / 14$ \\
\hline
\end{tabular}

Females

\begin{tabular}{c|cccc|cccc}
\hline $\mathrm{I}^{1}$ & 0.02 & 0.22 & -0.03 & -0.09 & 0.17 & $\mathbf{0 . 2 8}$ & 0.02 & -0.07 \\
$\mathrm{I}^{2}$ & 0.16 & -0.06 & $-\mathbf{0 . 2 4}$ & 0.22 & 0.19 & 0.02 & -0.07 & 0.05 \\
$\mathrm{C}^{\mathrm{s}}$ & 0.26 & 0.15 & 0.11 & 0.24 & 0.23 & 0.17 & 0.00 & 0.17 \\
$\mathrm{P}^{3}$ & 0.07 & 0.21 & 0.17 & 0.24 & -0.07 & 0.12 & $\mathbf{0 . 3 7}$ & 0.10 \\
$\mathrm{P}^{4}$ & 0.14 & $\mathbf{0 . 2 7}$ & $\mathbf{0 . 3 3}$ & 0.21 & -0.08 & 0.16 & $\mathbf{0 . 4 2}$ & 0.13 \\
$\mathrm{M}^{1}$ & -0.08 & $\mathbf{0 . 3 6}$ & 0.15 & 0.09 & -0.17 & $\mathbf{0 . 3 0}$ & -0.01 & 0.06 \\
$\mathrm{M}^{2}$ & 0.24 & $\mathbf{0 . 3 6}$ & 0.24 & $\mathbf{0 . 3 4}$ & $\mathbf{0 . 3 5}$ & $\mathbf{0 . 3 3}$ & 0.25 & -0.07 \\
$\mathrm{I}_{1}$ & -0.11 & 0.16 & 0.20 & 0.06 & -0.11 & 0.15 & -0.04 & 0.07 \\
$\mathrm{I}_{2}$ & 0.10 & 0.10 & 0.17 & 0.16 & 0.10 & 0.17 & -0.06 & 0.09 \\
$\mathrm{C}_{\mathrm{s}}$ & 0.08 & 0.16 & 0.06 & -0.04 & 0.27 & 0.21 & -0.01 & 0.13 \\
$\mathrm{P}_{3}$ & -0.10 & 0.24 & 0.15 & 0.11 & 0.27 & 0.20 & $\mathbf{0 . 2 8}$ & 0.14 \\
$\mathrm{P}_{4}$ & -0.05 & 0.23 & 0.10 & 0.15 & $\mathbf{0 . 3 7}$ & 0.23 & 0.22 & 0.19 \\
$\mathrm{M}_{1}$ & 0.10 & 0.23 & 0.21 & 0.17 & 0.09 & $\mathbf{0 . 3 0}$ & 0.19 & 0.09 \\
$\mathrm{M}_{2}$ & 0.03 & 0.33 & -0.04 & 0.14 & -0.18 & $\mathbf{0 . 4 0}$ & 0.14 & 0.03 \\
\hline ratio & $0 / 14$ & $3 / 14$ & $2 / 14$ & $1 / 14$ & $2 / 14$ & $5 / 14$ & $3 / 14$ & $0 / 14$ \\
a: this study & & & & & &
\end{tabular}


c: White Americans (Ohio) (Garn et al. 1965)

d: Afro-Americans (St Louis) (Henderson and Corruccini 1976

MD: mesiodistal, BL: buccolingual. In bold, significant correlations at $\mathrm{p}<0.05$. 
Figure 1

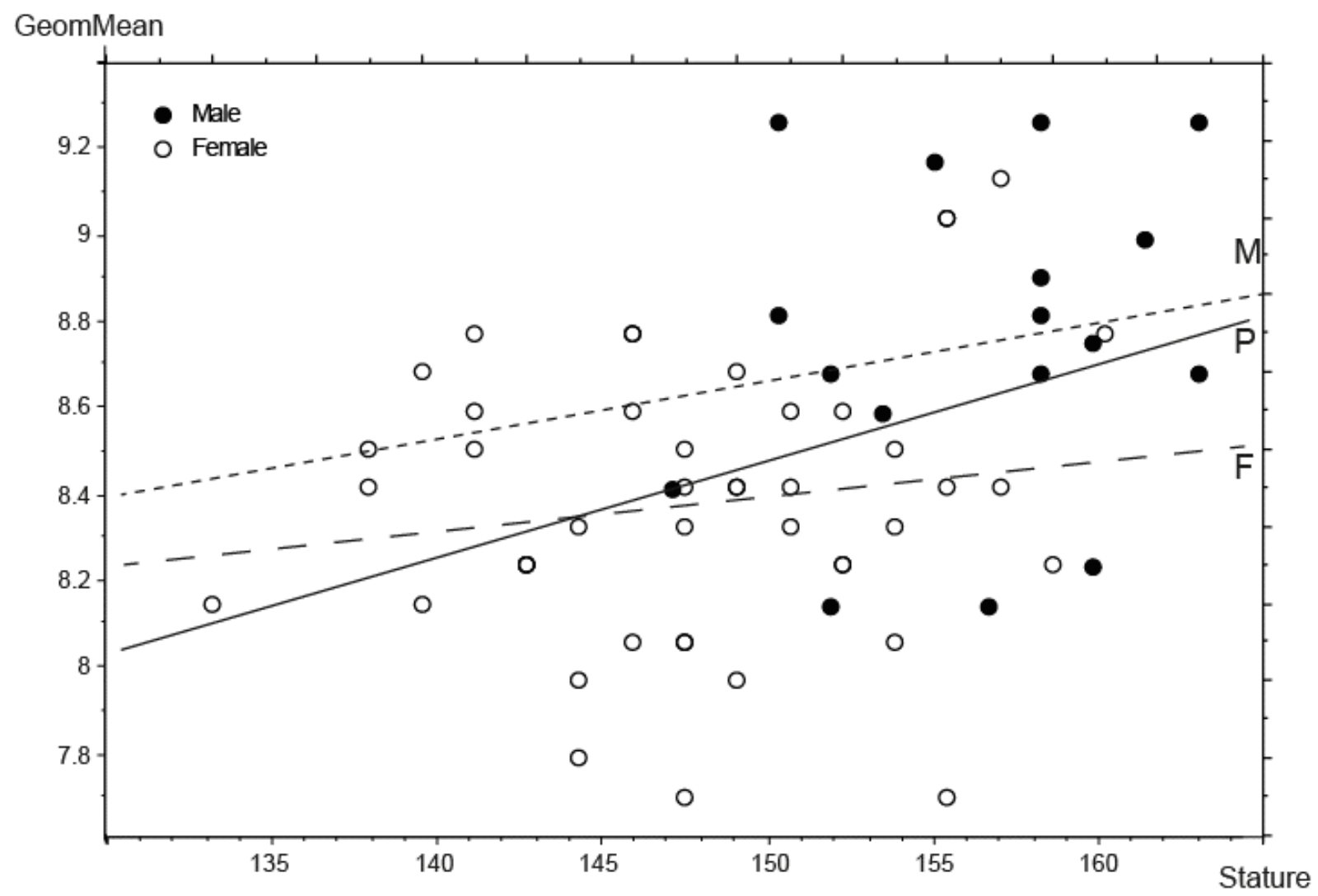


Figure Legends

Figure 1: Regression in females $(\mathrm{F})\left(\mathrm{y}=6.881+0.01 \mathrm{x} ; \mathrm{r}^{2}=0.031\right)$ and in males $(\mathrm{M})$ $\left(y=6.239+0.016 ; r^{2}=0.04\right)$ are not significant, but when the sexes are taken together, the regression $(\mathrm{P})\left(\mathrm{y}=5.126+0.022 ; \mathrm{r}^{2}=0.153\right)$ becomes significant $(\mathrm{p}<0.01)$ although the coefficient of determination remains low. 